\title{
Małgorzata Dajnowicz
}

https://orcid.org/0000-0001-6124-9983

Uniwersytet w Białymstoku

\section{Program działalności organizacyjno-propagandowej Ligi Kobiet na podstawie wytycznych Krajowych Zjazdów Ligi Kobiet}

Słowa kluczowe: Liga Kobiet, propaganda, Polska Ludowa, Zjazdy Ligi Kobiet, ruch kobiecy

\section{Streszczenie}

Realizacja zadań programowych i plany aktywności Ligi Kobiet ogłaszane były podczas zjazdów, mających charakter propagandowy i informujący odbiorczynie o kierunkach rozwoju organizacji, co miało przynieść rezultat w umocnieniu pozycji Ligi w różnych środowiskach kobiet. Podczas pierwszego w 1951 r. głównym wysuwanym postulatem była walka o pokój i wyznaczanie zadań dla organizacji, związanych z realizacją planu 6-letniego. Okresem podsumowań etapu działalności i form rozwoju Ligi miał być trzeci zjazd z 1962 r. Jednym z najważniejszych w okresie funkcjonowania Ligi Kobiet był zjazd czwarty, zorganizowany w 1966 r. Wówczas to ogłoszono odnowiony program organizacji, formy i metody działania w warunkach „nowego” rozwoju, w okolicznościach, kiedy to kilka miesięcy przed zjazdem organizacja przestała funkcjonować w zakładach pracy. Podczas dyskusji zjazdowej informowano uczestniczki o konieczności rozwoju Ligi w miejscu zamieszkania kobiet, natomiast w podjętej uchwale podkreślano temat aktywniejszego niż przedtem włączenia się kobiet w budowę Polski socjalistycznej. Dotychczasową działalność Ligi oceniano wówczas jako pozytywną lecz niewystarczającą, z powodu m.in. wciąż niedostatecznej liczebności członkiń. Wydarzeniem przełomowym, podczas którego przyjęto uchwałę o zmianie nazwy organizacji z Ligi Kobiet na Ligę Kobiet Polskich, był zjazd z 1981 r. Podczas dziewiątego zjazdu, w 1986 r., mimo odczuwalnej w społeczeństwie polskim nasilającej się atmosfery napięcia, związanej z kryzysem ekonomicznym i politycznym, skupiano się na postulatach propagandowych, dotyczących głoszenia umacniania pozycji kobiety w życiu społeczno-politycznym oraz gospodarce narodowej. 


\section{Wprowadzenie}

Problematyka dotycząca całokształtu działalności Ligi Kobiet (LK) jako oficjalnego, akceptowanego przez władze Polski Ludowej ruchu kobiecego wciąż wymaga badań szczegółowych. W ostanim okresie opublikowano kilka tekstów naukowych, które stanowić mogą punkt wyjściowy do opracowania całościowego na temat zasięgu działalności LK w latach 1945 - 1989 w poszczególnych województwach Polski, czyli w tzw. terenie, na poziomie regionalnym i lokalnym, w odniesieniu zwłaszcza do ośrodków miejskich. W obiegu naukowym znalazły się wartościowe artykuły traktujące o funkcjonowaniu LK w takich regionach jak województwo białostockie ${ }^{1}$, łódzkie ${ }^{2}$ czy Dolny Śląsk ${ }^{3}$.

LK prowadząca działalność w środowiskach kobiecych od 1945 do 1989 r. funkcjonowała pod trzema nazwami (Społeczno-Obywatelskiej Ligi Kobiet, Ligi Kobiet, Ligi Kobiet Polskich) i była jedynym oficjalnym, akceptowanym przez władze ruchem, skupiającym różne środowiska kobiet. Program działalności organizacji tworzony był w oparciu o wytyczne partii komunistycznej i rządu. Zadania do realizacji określane na poszczególne lata działalności oraz plany rozwoju ruchu ogłaszane były m.in. podczas krajowych zjazdów LK, kiedy to także informowano opinię publiczną, w tym członkinie o kierunkach rozwoju Ligi oraz zmianach w zasadniczych obszarach dalszej aktywności.

W sprawozdaniu pt. „Rozwój Ligi Kobiet w okresie od 1945 do 1951 roku" podano, że nadrzędnym celem określonym przez Zarząd Główny LK było „zbudowanie masowego, demokratycznego ruchu kobiecego w Polsce,

$1 \quad$ M. Dajnowicz, Główne kierunki działalności Ligi Kobiet w Polsce Ludowej do 1975 roku (ze szczególnym uwzględnieniem województwa białostockiego), „Prace Historyczne” 2018, nr 145(3), s. 579-601; Eadem, Liga Kobiet $w$ terenie. Kierunki działalności organizacji na przykładzie struktur białostockich w latach 1966-1981, „Niepodległość i Pamięć” 2018, t. 25, nr 2, s. 161-182; A. Drozdowska, Liga Kobiet w województwie białostockim - stan badań $i$ postulaty badawcze, „Czasopismo Naukowe Instytutu Studiów Kobiecych” 2018, nr 2(5), s. 112-127.

2 M. Dajnowicz, Liga Kobiet w okręgu łódzkim w latach 1945-1981. Główne obszary działalności, „Dzieje Najnowsze” 2019, nr 4, s. 75-90.

3 A. Miodowski, Local conditions for the activities of the League of Women structures in the Lower Silesia during the Stalinist period, „Społeczeństwo i Polityka” 2018, nr 4(57), s. 137-155; Idem, Udział dolnoślaskiej Ligi Kobiet w kampaniach propagandowych na rzecz aktywizacji zawodowej kobiet ze środowisk patologicznych i aspołecznych (19491955), „Niepodległość i Pamięć” 2019, t. 26, nr 1, s. 279-302. 
opartego o szeroką rekrutację kobiet ze wszystkich warstw społecznych"4. Najważniejszym więc celem stawianym przez organizację było zbudowanie jej masowości pod względem liczebności członkiń. W pierwszych latach rozwoju Ligi, do początków lat pięćdziesiątych, podejmowano działania głównie na rzecz upowszechniania zatrudnienia kobiet oraz dokształcania, w tym drugim przypadku, w zakresie edukacji, miały być to licznie inicjowane przez LK kursy dla analfabetek ${ }^{5}$.

W okresie przygotowań do I Zjazdu Krajowego LK w 1951 r. , w stosunku do okresu wcześniejszego, zmieniła się polityka władz komunistycznych wobec kobiet. Związane było to $\mathrm{z}$ wdrażaniem przez państwo planu sześcioletniego i szeroko zakrojonej akcji zwiększania w Polsce zatrudnienia kobiet ${ }^{6}$. W przekazie propagandowym także samej Ligi pojawiały się krytyczne opinie na temat uzależnienia jej od partii, wskazywano na brak samodzielności LK jako szeroko rozumianego ruchu kobiecego ${ }^{7}$. W wypowiedziach propagandowych LK podkreślano jednocześnie konieczność dążenia organizacji do zrównania praw kobiet z mężczyznami w odniesieniu do pracy zawodowej. Zrównanie praw kobiet i mężczyzn w pracy wynikało z upowszechniania w Polsce Ludowej wzoru kobiety, opartego na wizerunku kobiety radzieckiej. Równość kobiet i mężczyzn w pracy zawodowej miała być jednym $\mathrm{z}$ ważnych i eksponowanych $\mathrm{w}$ przekazie propagandowym osiągnięć komunistycznego systemu wprowadzanego wówczas w Polsce. Uwieńczeniem zrównania praw kobiet i mężczyzn od strony formalno-prawnej miały być zapisy konstytucji z 1952 r., zapewniające równe prawa oraz obowiązki kobiet i mężczyzn we wszystkich obszarach życia społecznego ${ }^{8}$.

4 Archiwum Akt Nowych, Polska Zjednoczona Partia Robotnicza, Komitet Centralny, Wydział Kobiecy, 237/XV-30, Rozwój Ligi Kobiet w okresie od 1945-1951 r., k. 1.

$5 \quad$ Zob. szerzej M. Dajnowicz, Działalność Społeczno-Obywatelskiej Ligi Kobiet w świetle „Naszej Pracy” (1947-1949), [w:] M. Dajnowicz, A. Miodowski (red.), Polityka i politycy w prasie XX i XXI wieku, Wydawnicwo Uniwersytetu w Białymstoku, Białystok 2016, s. 295-307.

$6 \quad$ M. Fidelis, Kobiety, komunizm i industrializacja $w$ powojennej Polsce, przeł. M. Jaszczurowska, Grupa Wydawnicza Foksal, Warszawa 2015, s. 79.

$7 \quad$ M. Grabowska, Zerwana genealogia. Działalność społeczna i polityczna kobiet po 1945 roku a współczesny polski ruch kobiecy, Instytut Filozofii i Socjologii PAN, Warszawa 2018, s. 230-231.

$8 \quad$ M. Dajnowicz, Główne kierunki działalności Ligi Kobiet w Polsce Ludowej do 1975 roku (ze szczególnym uwzględnieniem województwa białostockiego), „Prace Historyczne" 2018, nr 145(3), s. 58 i nast. 
Podczas Zjazdu w 1951 r. głównymi hasłami wysuwanymi przez uczestniczki była walka o pokój oraz włączenie się kobiet w realizację planu sześcioletniego. Wśród zadań głównych Ligi wymieniano

pogłębienie wśród kobiet uczuć międzynarodowej solidarności ze wszystkimi walczącymi o pokój, ich włączenie do wszystkich akcji pokojowych, podejmowanych przez polskie masy ludowe i cały obóz antyimperialistyczny, włączanie kobiet do Komitetów Obrony Pokoju, zacieśnienie współpracy Ligi Kobiet ze Światową Demokratyczną Federacją Kobiet".

Podczas Zjazdu uchwalono również nowy statut $\mathrm{LK}^{10}$. Zgodnie $\mathrm{z}$ forsowanym przez ówczesną władzę politycznym kierunkiem propagandowym, kobiety polskie stanowić miały część ogólnoświatowego systemu, skupiającego wszystkie kobiety działające na rzecz światowego pokoju. W wysuwanych hasłach propagandowych odnoszących się do walki o pokój łączono również kwestię zabezpieczenia pokoju Polski i świata z bezpieczeństwem rodzin, odnoszono się do ról społecznych kobiet jako matek i opiekunek ognisk domowych, gdzie przy upowszechnianym i wręcz eksponowanym haśle walki kobiet o pokój występowała jednocześnie kwestia konieczności zapewnienia bezpieczeństwa rodzinom. W referacie zjazdowym przewodniczącej Zarządu Głównego LK Alicji Musiałowej pt. Kobieta w walce o pokój i plan sześcioletni liderka podkreślała, że ostoją pokoju i jego gwarantem jest „rosnąca wciąż potęga i moc Związku Radzieckiego oraz jego konsekwentna polityka pokojowa" ${ }^{11}$. W referacie podczas Zjazdu Musiałowa mówiła o konieczności łączenia się kobiet świata we wspólnym froncie poparcia dla pokoju, m.in. w działalności Światowej Demokratycznej Federacji Kobiet. Podkreślała, że w narodowym froncie walki o pokój i socjalizm obowiązki nakłada się na kobiety polskie reprezentujące różne grupy, w tym robotnice, chłopki, inteligentki. Zabezpieczenie pokoju odbywać by się miało poprzez codzienną pracę kobiet, udział we współzawodnictwie pracy, również w różnorodnej pracy wychowawczej w odniesieniu do młodego pokolenia ${ }^{12}$.

Ramowy plan Pracy Ligi Kobiet na rok 1951, „Nasza Praca” 1951, nr 2, s. 6.

10 J.B., Kongres uchwala statut Ligi Kobiet, „Nasza Praca” 1951, nr 3-4, s. 2-3.

11 A. Musiałowa, Zadania kobiet polskich w walce o pokój i plan 6-letni, „Nasza Praca” 1951, nr 6-7, s. 27, 34.

12 A. Musiałowa, Zadania kobiet polskich $w$ walce o pokój i plan 6-letni, „Nasza Praca” 1951, nr 6-7, s. 36-37; Eadem, „Walka o pokój” w wypowiedziach propagandowych publikowanych na łamach „Naszej Pracy” - biuletynie Ligi Kobiet (1947-1953), [w:] E. Maj, W. Sokół, A. Szwed-Walczak, Ł. Jędrzejski (red.), Bezpieczeństwo Europy 
Od połowy lat pięćdziesiątych zmieniał się stosunek władz do roli i postrzegania miejsca kobiet w społeczeństwie. Promowana w czasie stalinizmu produktywizacja została zastąpiona upowszechnianiem idei powrotu kobiet do domu. Na planie pierwszym w życiu kobiet miała znajdować się dbałość o rodzinę i wychowanie dzieci, na dalszym - praca zawodowa. Zajęcia domowe i rodzinne miały być nadrzędne w życiu kobiety. Powołana przez władze w połowie lat pięćdziesiątych Krajowa Rada Matek miała dowodzić, że matki polskie miały trudności w wychowaniu dzieci i potrzebowały wsparcia $\mathrm{w}$ tym zakresie. W związku $\mathrm{z}$ tym LK powinna angażować się w prowadzenie poradni dla kobiet i dzieci, współdziałać z sądami dla nieletnich w kwestii rozwiazywania problemów wychowawczych dotyczących dzieci i młodzieży ${ }^{13}$. Do zasadniczych zadań organizacji w drugiej połowie lat pięćdziesiątych należało szkolenie kobiet zrzeszonych w organizacji jak i nie należących do Ligi, głównie w zakresie prowadzenia domu, $\mathrm{w}$ tym oszczędnego a zarazem nowoczesnego gospodarstwa domowego oraz spraw dotyczących rodziny ${ }^{14}$.

II Krajowy Zjazd LK obradował w 1957 r. Alicja Musiałowa w przedstawionym wówczas referacie poddała krytyce dotychczasowy model działalności Ligi podkreślając, że organizacja nie była dotąd dość skuteczna w rozwiązywaniu codziennych problemów kobiet. W czasie Zjazdu podjęto uchwałę dotyczącą zaangażowania Ligi w zakresie pomocy kobietom pracującym. Pomoc ta miała polegać przede wszystkim na zaangażowaniu liderek z Ligi w organizację żłobków, przedszkoli, poradni świadomego macierzyństwa. Miała być to pomoc udzielana matkom pracującym również zawodowo. Podczas Zjazdu uchwalono nowy statut, w którym zaakcentowano potrzebę tworzenia $\mathrm{w}$ dalszej działalności LK kół tzw. lokalnych, odpowiedzialnych za rozwiązywanie konkretnych problemów kobiet, płynących z potrzeb różnych środowisk kobiecych z miast, gmin, osiedli miejskich $^{15}$.

Okresem podsumowań etapu działalności i form rozwoju Ligi miał być Zjazd Krajowy zorganizowany przez Ligę w 1962 r. Wówczas LK oceniła

- Bezpieczeństwo Polski: Metamorfozy bezpieczeństwa. Teraźniejszość i przeszłość, t. 5, Wydawnictwo UMCS, Lublin 2017, s. 409-421.

13 Wstępna analiza pracy Ligi Kobiet w okresie 10-lecia jej istnienia, „Nasza Praca” 1956, nr 1, s. 7.

1465 Ligi Kobiet Polskich w Łodzi we wspomnieniach Jej członkiń 1945-2010, Łódź 2010, s. 27.

15 M. Musiałowa, Referat przewodniczącej ZG LK Alicji Musiałowej wygłoszony na II Zjeździe LK, [w:] Materiały II Zjazdu LK w dniach 11-13 lipca 1957 r., Warszawa 1957, s. 3-28. 
pozytywnie swoje dotychczasowe wysiłki w zakresie wypracowania modelu współczesnej kobiety, łączącej z powodzeniem życie prywatne z aktywnością zawodową. Mówiono także o wzrastającej roli kobiety w życiu publicznym, większym niż wcześniej zaangażowaniu Polek w życie zawodowe, informowano, że z upływem czasu zwiększał się odsetek kobiet z wykształceniem wyższym i średnim oraz „często przodująca ich rola w inicjatywach społecznych, kulturalnych i innych, co świadczy o rosnącej świadomości obywatelskiej kobiet" ${ }^{\prime 6}$. W uchwale podjętej podczas III Krajowego Zjazdu LK w 1962 r. wskazywano na dotychczasowe osiągnięcia kobiet w Polsce Ludowej, czego dowodem miała być zwiększająca się liczba szeregowych członkiń LK jak i liderek organizacji. LK mogła wskazać wówczas na poszerzającą się współpracę z rożnymi środowiskami kobiecymi, związkami zawodowymi, Kołami Gospodyń Wiejskich, spółdzielniami. Przy zarządach LK miały prowadzić działalność poradnie prawne i punkty lekarskie, powoływane były kluby do prowadzenia pracy kulturalnej i oświatowej również wśród kobiet niepracujących. W celu poszerzenia pracy ideowo-wychowawczej członkinie Ligi powoływać miały kolejne placówki w miastach, tzw. kluby osiedlowe i tzw. koła blokowe ${ }^{17}$. Liga miała się skupić na powstawaniu nowych placówek organizacji i rozwijaniu już istniejących.

Jednym $\mathrm{z}$ najważniejszych $\mathrm{w}$ okresie funkcjonowania organizacji był IV Krajowy Zjazd LK, zorganizowany w 1966 r. Wówczas to ogłoszono nowy program organizacji, zapowiedziano inne niż dotychczas formy i metody działania, w warunkach „nowego rozwoju kraju”, w okolicznościach, kiedy to kilka miesięcy przed Zjazdem organizacja przestała funkcjonować w zakładach pracy. Podczas dyskusji informowano uczestniczki Krajowego Zjazdu o konieczności dalszego rozwoju Ligi w miejscu zamieszkania kobiet oraz w podjętej uchwale podkreślano temat aktywniejszego niż przedtem włączenia się kobiet w budowę Polski socjalistycznej. Dotychczasową działalność Ligi oceniano pozytywnie, choć zapowiedziano dalsze zaangażowanie na rzecz wciąż niedostatecznej liczebności jej członkiń. Podczas Zjazdu podkreślano potrzebę zaangażowania liderek w pracę w środowiskach kobiet niepracujących, w miastach, miasteczkach,

16 W. Jackowska, Kier. Wydz. Org. ZG LK, Przed II Krajowym Zjazdem Ligi Kobiet, „Nasza Praca” 1962, nr 2, s. 5.

17 Archiwum Ligi Kobiet Polskich w Łodzi, Uchwała III Krajowego Kongresu Ligi Kobiet, Warszawa, 19 luty 1962 r., s. 1-9. 
osiedlach miejskich ${ }^{18}$. Szczególne znaczenie w kierunkach dalszego rozwoju organizacji i umacniania jej pozycji w środowiskach kobiet niezrzeszonych przypisywano powoływaniu i aktywności kół w miejscu zamieszkania kobiet. Działania Ligi skupiać się miały na wzmocnieniu roli kobiet w przestrzeni Polski socjalistycznej, zarówno w rodzinie, pracy zawodowej jak i życiu publicznym ${ }^{19}$. W 1967 r. numer „Naszej Pracy” poświęcono efektom realizacji uchwały z IV Zjazdu Ligi Kobiet z 1966 r. W treści prasowego materiału sprawozdawczego podawano, że do najważniejszych osiągnięć, wyznaczonych do realizacji podczas dyskusji zjazdowej, należało rozbudowanie placówek terenowych (w tym tzw. komitetów blokowych) w miastach i miasteczkach kraju. Ponadto podkreślano znaczenie rozbudowywanych placówek Komitetu Gospodarstwa Domowego, których działalność miała zaradzić ogólnospołecznemu problemowi odciążenia kobiet w licznych obowiązkach domowych, zwłaszcza kobiet pracujących zawodowo ${ }^{20}$.

Lata sześćdziesiąte i początek siedemdziesiątych to najbardziej aktywny i wydaje się, że najbardziej owocny okres w rozwoju $\mathrm{LK}^{21}$. Od począt$\mathrm{ku}$ lat siedemdziesiątych $\mathrm{w}$ dyskursie propagandowym LK dominowała natomiast tematyka dotycząca Międzynarodowego Roku Kobiet, przypadającego w 1975 r. W celu nadania odpowiednej rangi wydarzeniom związanym z Rokiem Kobiet, Rada Ministrów PRL podjęła w 1974 r. uchwałę, w której opisano obowiązki organizacji społecznych w zakresie „różnorodnych działań zmierzających do polepszenia warunków życia i pracy kobiet, a w konsekwencji do podniesienia na jeszcze wyższy poziom ich pozycji społeczno-zawodowej i rodzinnej”. Wszelkie akcje społeczne podejmowane na rzecz środowisk kobiecych i organizowane przez Ligę w osiedlach miejskich oraz inne szeroko rozumiane inicjatywy na szczeblu lokalnym, w tym organizacja kursów, akcji oświatowych, wszelkich inicjatyw organizowanych i inicjowanych przez Ligę miały zyskać podniosły

18 Archiwum Narodowe w Krakowie, Materiał pomocniczy do opracowania prelekcji, referatów i pogadanek okolicznościowych z okazji XX-lecia Ligi Kobiet, Spuścizna Janiny Jasickiej, sygn. 29/1340/99, k. 454-455

19 Rola i zadania Ligi Kobiet na tle rozwoju ruchu kobiecego jego nowych potrzeb i możliwości. Referat wygłoszony przez przewodnicząca Zarządu Głównego LK Stanisławe Zawadecka, [w:] Materiały z obrad IV Krajowego Zjazdu Ligi Kobiet 26-28 czerwca 1966 r., b.r.w., s. 14-18.

20 Realizacja uchwały IV Krajowego Zjazdu Ligi Kobiet i kierunki dalszej działalności. Referat Prezydium ZG LK wygłoszony na II Plenum w dniu 3 lutego 1967 r., „Nasza Praca" 1967, nr 2, s. 3-25.

$21 \quad$ Sprawozdanie z działalności Ligi Kobiet za lata 1966-70, Warszawa 1970, s. 4-30 i nast. 
i uroczysty charakter w czasie obchodów w 1975 r. Międzynarodowego Roku Kobiet ${ }^{22}$.

Podczas VIII Nadzwyczajnego Zjazdu Krajowego LK w 1981 r. podkreślano konieczność większego zaangażowania Ligi w zakładach pracy zatrudniających kobiety oraz włączenia się liderek i szeregowych członkiń w prace na rzecz przeciwdziałania kryzysowi oraz jego skutkom, zwłaszcza ekonomicznym. Obrady zainaugurowano referatem programowym ustępującego Zarządu Głównego LK, którego tematem były zagadnienia historii działalności ruchu kobiecego w Polsce Ludowej, głównych obszarów aktywności LK i jej dokonań począwszy od 1945 r. Wśród osiągnięć organizacji wskazywano m.in. na kwestie dotyczące angażowania się liderek $\mathrm{z}$ Ligi w prace opiniodawcze w zakresie powstających wówczas ustaw, dotyczące chociażby prawa rodzinnego i alimentacyjnego, co stać miało w sprzeczności z funkcjonującą w części społeczeństwa opinią na temat Ligi, postrzeganej jako „reprezentacji wyłącznie emerytek lub miejskich gospodyń domowych, które winny zajmować się kuchnią, klatką schodową i podwórkiem"23. Dowodzono w dyskusjach zjazdowych, właśnie wbrew niektórym opiniom społecznym, że LK w swej wieloletniej działalności przyczyniała się do rozwiązania wielu ogólnospołecznych problemów, chociażby poprzez edukowanie Polek w zakresie prowadzenia nowoczesnego i oszczędnego gospodarstwa domowego czy stosowania w życiu codziennym zdrowych zasad żywieniowych, upowszechnianych następnie w polskich rodzinach. Podczas Zjazdu mówiono także o słabościach Ligi i popełnianych w przeszłości błędach, wynikających, jak informowano, z jej niedostatecznego zaangażowania w szeroko rozumiane problemy kobiet ${ }^{24}$.

Przyznanie się do błędów popełnianych w działaniach organizacji w przeszłości miało wzbudzić większe zaufanie kobiet do LK, zrzeszonych i nie należących do organizacji, uzasadniać zmiany w wytyczaniu po 1981 r. dalszych działań Ligi, funkcjonującej już pod nową, szerszą nazwą Ligi Kobiet Polskich (LKP). W celach Zjazdu akcentowano również potrzebę wypracowania koncepcji prowadzącej do wzmocnienia wśród Polek pozycji i autorytetu LKP, odnowionej w swych strukturach, bardziej masowej i jednocześnie nowocześniejszej niż przed 1982 r., reprezentującej interesy wszystkich kobiet polskich, z różnych środowisk społecznych,

22 Zarząd Główny Ligi Kobiet, Program działania Ligi Kobiet w Międzynarodowym Roku Kobiet, „Nasza Praca” 1975, nr 1-2, s. 9-17.

23 A jednak działała, „Nasza Praca” 1981, nr 1, s. 11.

24 Nie może być demokracji bez kobiet, „Nasza Praca” 1981, nr 1, s. 16-17. 
zawodowych, grup pokoleniowych, na co wskazywać miała właśnie jej szersza nazwa ${ }^{25}$. LKP miała być organizacją

nie tylko z osiedla, Ligą Kobiet nie tylko emerytek, gospodyń domowych bo i takie wyobrażenie w Lidze panowało dotychczas w środkach masowego przekazu - lecz ma być to Liga wszystkich Polek, które uznają ją za swoją, Polek pracujących zawodowo i prowadzących gospodarstwa rodzinne, młodych i starszych, robotnic i naukowców, kobiet wszystkich środowisk i zawodów,

pisano w relacji ze zjazdu, publikowanej na łamach „Naszej Pracy”26.

Zakładano, że do działań priorytetowych organizacji należeć będzie dążenie do pełnego równouprawnienia kobiet z mężczyznami, ze szczególnym uwzględnieniem zapewnienia kobietom polskim równych płac z mężczyznami oraz równego dostępu do zawodów, zwłaszcza o szczególnym prestiżu społecznym. LKP miałaby z jednej strony nawiązywać częściowo do długoletniego dorobku LK, z drugiej zaś strony otwierać się miały dla niej nowe perspektywy aktywności, dotyczące większego niż dotychczas angażowania się w sprawy dotyczące różnych środowisk kobiecych ${ }^{27}$. Aktywność LKP w zakładach zatrudniających kobiety zapewnić jej miało bardziej ugruntowane wpływy wśród kobiet pracujących. Przewodnicząca ZG LK Jadwiga Biedrzycka podkreślała w przemówieniu podczas zjazdu, że w programie organizacji priorytetowo traktowane będą sprawy kobiet, dotyczące utrzymania ich godnej pozycji w społeczeństwie, równych praw kobiet i mężczyzn w rodzinie, życiu zawodowym i publicznym. Uważała, że organizacja powinna działać bardziej zdecydowanie niż w przeszłości, żądać jednocześnie od władz rządowych spełnienia wysuwanych przez nią konkretnych postulatów, dotyczących zwłaszcza polepszenia codziennego życia kobiet. Do osiągnięcia tych celów niezbędna miała być aktywność

25 Zob. I. Ratman-Liwerska, Stowarzyszenie jako czynnik społeczno-wychowawczej aktywizacji kobiet (na przykładzie badań na Białostocczyźnie), Dział Wydawnictw Filii UW, Białystok 1984, s. 96.

26 Liga wszystkich Polek, „Nasza Praca” 1981, nr 1, s. 18.

27 Zob. M. Dajnowicz, „Zwierciadło” - platforma polityczna Ligi Kobiet w okresie PRL (1957-1961, 1982-1989), „Rocznik Historii Prasy Polskiej” 2017, nr 3, s. 82-87; Eadem, Posłanki Ligi Kobiet Polskich i wybory parlamentarne 1989 roku (prezentacja w świetle „Zwierciadła”), [w:] M. Dajnowicz, A. Miodowski (red.), Polityka i politycy $w$ prasie XX $i$ XXI wieku. Polityka $w$ prasie kobiecej, Wydawnictwo Uniwersytetu w Białymstoku Białystok 2018, s. 205-215; A. Drozdowska, Liderki Ligi Kobiet wobec wyborów w latach 80. (w świetle „Naszej Pracy”), „Czasopismo Naukowe Instytutu Studiów Kobiecych” 2020, nr 1(8), s. 198-205. 
kobiet $\mathrm{w}$ różnorodnych działaniach $\mathrm{w}$ życiu zawodowym i publicznym oraz wprowadzenie $\mathrm{w}$ państwie polskim korzystnych dla kobiet zmian, m.in. poprzez ustawodawstwo dotyczące stricte kobiet ${ }^{28}$. Zjazd zakończył się podjętą uchwałą o zmianie nazwy organizacji LK na LKP ${ }^{29}$.

Praca zawodowa, zwłaszcza w warunkach narastającego kryzysu ekonomiczno-politycznego w latach osiemdziesiątych i związanego $z$ tym niezadowolenia społecznego miała być stawiana na pierwszym planie w życiu kobiety, być kluczową wartością związaną z interesem zakładu pracy, ważniejszym niekiedy od interesu jednostki, czyli w tym przypadku pracującej kobiety $^{30}$. Praca miała łączyć kobiety pracujące $w$ ich społecznym funkcjonowaniu, zapewniając jednocześnie środki ekonomiczne niezbędne w codziennym życiu kobiet i ich rodzin. Praca zawodowa stwarzać miała dla samych kobiet także możliwości rozwoju organizacyjnego i społecznego oraz karier zawodowych, stawała się ich wkładem w „budowanie i utrzymanie Polski socjalistycznej" ${ }^{31}$.

W 1986 r. odbył się IX Zjazd Krajowy LKP, podczas którego przyjęto program działania organizacji do $1990 \mathrm{r}$. W wytycznych programowych podkreślano konieczność większej aktywności niż dotychczas kół zakładowych, które, m.in. „usuwać powinny bariery hamujące awans kobiet”. Zakładano ponadto dalszy rozwój poradnictwa dla kobiet, zwłaszcza rodzinno-prawnego. Za kwestię priorytetową uznawano dalszą działalność Ligi w zakładach pracy i zwiększanie liczby członkiń, rekrutowanych pośród młodych kobiet. Harmonijną współpracę Polek zrzeszonych i niezrzeszonych w Lidze upowszechniać miały obchody Międzynarodowego Dnia Kobiet organizowane w 1987 r. ogłoszone przez Ligę Kongresem Kobiet ${ }^{32}$.

28 Chcemy reprezentować interesy kobiet polskich, „Nasza Praca” 1982, nr 1, s. 28.

29 Uchwała programowa VIII Nadzwyczajnego Zjazdu Krajowego Ligi Kobiet, Warszawa, 28 listopada 1981 r., „Nasza Praca” 1982, nr 1, s. 45-51; Rozporządzenie Rady Ministrów z dnia 2 grudnia 1981 r. w sprawie zmiany nazwy stowarzyszenia wyższej użyteczności „Liga Kobiet” na „Liga Kobiet Polskich” oraz nadania statutu temu stowarzyszeniu, Dz.U. 1982 nr 38 poz. 254.

K. Andrejuk, Awans społeczny kobiet w czasach PRL. Dynamika struktury i sprawczości, „Przegląd Socjologiczny” 2016, t. 3, s. 170.

31 M. Madejska, Aleja włókniarek, Wydawnictwo Czarne, Wołowiec 2018, s. 179-180 i nast.

32 Instytut Pamięci Narodowej, BU 01728/52, Kierunki działania Ligi Kobiet Polskich w 1987 r. Projekt, Warszawa, styczeń 1987 r., k. 106-108; Sprawozdanie z działalności Ligi Kobiet w latach 1979-1981, Warszawa, listopad 1981, k. 82; Założenie przeglądu struktur organizacyjnych, atestacji stanowisk pracy oraz przegladu kadrowego $w$ Lidze Kobiet Polskich, b.d.w., k. 126. 
Mimo odczuwalnej w społeczeństwie polskim nasilającej się atmosfery napięcia, związanej z kryzysem ekonomicznym i politycznym, skupiano się na postulatach propagandowych, dotyczących głoszenia umacniania pozycji kobiety w życiu społeczno-politycznym oraz gospodarce narodowej. Za szczególnie istotną uznawano dalszą pomoc kobietom, w trudnym okresie lat osiemdziesiątych, dotyczącą przede wszystkim szeroko rozumianego poradnictwa. Służyć temu miały licznie zakładane przez liderki organizacji poradnie prawno-społeczne, rodzinne, gospodarstwa domowego. Program działalności Ligi określony na lata od 1986 r. miał wynikać także z oddolnych potrzeb kobiet. Dzięki staraniom Ligi powołano w tym roku pełnomocnika rządu ds. kobiet $^{33}$. W programie działania na lata 1986-1990 podkreślano także konieczność umacniania pozycji kobiet w życiu społeczno-politycznym i gospodarczym, udoskonalania modelu współczesnej rodziny funkcjonującej w oparciu o zasady partnerskie, propagowania etosu pracy zawodowej ${ }^{34}$.

\section{Podsumowanie}

Podczas Krajowych Zjazdów LK ogłaszano wytyczne do działań programowych LK, formułowano zadania do realizacji, oceniano dotychczasową działalność, przedstawiano publicznie cele rozwoju aktywności Ligi w różnych środowiskach kobiecych. Informacje podawane uczestniczkom podczas tych Zjazdów miały również charakter propagandowy, upowszechniający znaczenie szerokiej działalności LK i odzwierciedlały w pewnym zakresie politykę władz rządowo-partyjnych wobec kobiet.

Podczas Zjazdu w 1951 r. eksponowano zagadnienie znaczenia pracy zawodowej kobiet ze szczególnym uwzględnieniem współzawodnictwa i zaangażowania kobiet $\mathrm{w}$ realizację planu sześcioletniego. Za kluczowe uznawano również upowszechnianie idei pokoju na świecie z głównym hasłem propagandowym walki o pokój. W związku ze zmianą polityki władz wobec kobiet w okresie od połowy lat pięćdziesiątych podczas Zjazdu w 1957 r. ogłoszono program oscylujący wobec spraw znaczenia domu, rodziny i dzieci jako nadrzędnych w życiu kobiety. Praca zawodowa, we wcześniejszym okresie zajmująca istotne miejsce w przekazie LK, zeszła na plan dalszy w związku z realizacją propagandowego hasła "powrotu kobiet do domu”. Zasygnalizowano wówczas także temat znaczenia two-

33 Referat sprawozdawczo-programowy wygłoszony przez Jadwige Biedrzycka 12 października 1986 r., „Nasza Praca” 1986, nr 12, s. 6-14.

34 Program działania Ligi Kobiet Polskich na lata 1986-1990 przyjęty na IX Krajowym Zjeździe, „Nasza Praca” 1986, nr 12, s. 18-20. 
rzenia kół lokalnych w celu większego niż dotychczas budowania wpływów Ligi wśród kobiet $\mathrm{z}$ osiedli miejskich, także niepracujących. Do kwestii dotyczącej większego zaangażowania organizacji w propagowanie pogodzenia życia rodzinnego kobiet $\mathrm{z}$ aktywnością zawodową nawiązywano podczas Zjazdu w 1962 r. Apelowano także w tym czasie w wytycznych programowych o większy udział kobiet w życiu publicznym, jednak kwestią najważniejszą wówczas podejmowaną wydawał się temat powoływania klubów osiedlowych, tworzenia punktów ligowych w miejscu zamieszkania kobiet. Problematyka rozbudowania struktur organizacji na osiedlach miejskich była kontynuowana podczas następnego Zjazdu LK w 1966 r. Wówczas to skupiono się także na upowszechnianiu znaczenia Komitetów Gospodarstwa Domowego, powoływanych przy Lidze i pomocy doradczo-szkoleniowej oferowanej ze strony Komitetów, kierowanej zwłaszcza do kobiet dzielących czas pomiędzy pracę a przestrzeń domową.

Zupełnie inny charakter miały Zjazdy organizowane w latach osiemdziesiątych. W 1982 r. Liga zmieniła nazwę na szerszą, co miało wzmocnić jej wiarygodność i co za tym idzie, wpływy w różnorodnych środowiskach kobiet. Zapowiadano podczas Zjazdu większe zaangażowanie LKP w zakładach pracy zatrudniających kobiety, nawiązywano do kwestii równości kobiet z mężczyznami w pracy, w rodzinie i w życiu publicznym. W $1986 \mathrm{r}$. kontynuowano postulaty $\mathrm{z}$ poprzedniego Zjazdu, kładziono wówczas nacisk na powoływanie kół zakładowych, w większej mierze wybrzmiały w postulatach zjazdowych kwestie konieczności udziału kobiet w sferze publicznej, umocnienia pozycji kobiety w życiu społeczno-politycznym, zawodowym, publicznym.

\section{Bibliografia}

\section{Źródła archiwalne}

Archiwum Akt Nowych, Polska Zjednoczona Partia Robotnicza, Komitet Centralny, Wydział Kobiecy, 237/XV-30, Rozwój Ligi Kobiet $w$ okresie od 1945-1951 r., k. 1.

Archiwum Narodowe w Krakowie, Materiał pomocniczy do opracowania prelekcji, referatów i pogadanek okolicznościowych z okazji XX-lecia Ligi Kobiet, Spuścizna Janiny Jasickiej, sygn. 29/1340/99, k. 454-455.

Instytut Pamięci Narodowej, BU 01728/52, Kierunki działania Ligi Kobiet Polskich w 1987 r. Projekt, Warszawa, styczeń 1987 r., k. 106-108. 
Rozporządzenie Rady Ministrów z dnia 2 grudnia 1982 r. w sprawie zmiany nazwy stowarzyszenia wyższej użyteczności „Liga Kobiet” na „Liga Kobiet Polskich” oraz nadania statutu temu stowarzyszeniu, Dz.U. $1982 \mathrm{nr} 38$ poz. 254.

Sprawozdanie z działalności Ligi Kobiet $w$ latach 1979-1981, Warszawa, listopad 1981, k. 82.

Sprawozdanie z działalności Ligi Kobiet za lata 1966 - 70, Warszawa 1970.

Uchwała programowa VIII Nadzwyczajnego Zjazdu Krajowego Ligi Kobiet, Warszawa, 28 listopada 1981 r., „Nasza Praca” 1982, nr 1.

Założenie przeglądu struktur organizacyjnych, atestacji stanowisk pracy oraz przegladu kadrowego w Lidze Kobiet Polskich, b.d.w., k. 126.

\section{Źródła publikowane}

Archiwum Ligi Kobiet Polskich w Łodzi, Uchwała III Krajowego Kongresu Ligi Kobiet, Warszawa, 19 luty 1962 r.

Musiałowa M., Referat przewodniczacej ZG LK Alicji Musiałowej wygłoszony na II Zjeździe LK, [w:] Materiały II Zjazdu LK w dniach 11-13 lipca 1957 r., Warszawa 1957.

Rola i zadania Ligi Kobiet na tle rozwoju ruchu kobiecego jego nowych potrzeb i możliwości. Referat wygłoszony przez przewodniczaca Zarządu Głównego LK Stanisławę Zawadecka, [w:] Materiały z obrad IV Krajowego Zjazdu Ligi Kobiet 26-28 czerwca 1966 r., b.r.w.

\section{Źródła prasowe}

65 Ligi Kobiet Polskich w Łodzi we wspomnieniach Jej członkiń 1945-2010, Łódź 2010.

A jednak działała, „Nasza Praca” 1981, nr 1.

Chcemy reprezentować interesy kobiet polskich, „Nasza Praca” 1982, nr 1.

J.B., Kongres uchwala statut Ligi Kobiet, „Nasza Praca” 1951, nr 3-4.

Jackowska W., Kier. Wydz. Org. ZG LK, Przed II Krajowym Zjazdem Ligi Kobiet, „Nasza Praca” 1962, nr 2.

Liga wszystkich Polek, „Nasza Praca” 1981, nr 1.

Nie może być demokracji bez kobiet, „Nasza Praca” 1981, nr 1.

Program działania Ligi Kobiet Polskich na lata 1986-1990 przyjęty na IX Krajowym Zjeździe, „Nasza Praca” 1986, nr 12.

Ramowy plan Pracy Ligi Kobiet na rok 1951, „Nasza Praca” 1951, nr 2.

Realizacja uchwały IV Krajowego Zjazdu Ligi Kobiet i kierunki dalszej działalności. Referat Prezydium ZG LK wygloszony na II Plenum w dniu 3 lutego 1967 r., „Nasza Praca”1967, nr 2.

Referat sprawozdawczo-programowy wygłoszony przez Jadwige Biedrzycka 12 października 1986 r., „Nasza Praca” 1986, nr 12. 
Wstępna analiza pracy Ligi Kobiet w okresie 10-lecia jej istnienia, „Nasza Praca” 1956, nr 1.

Zarząd Główny Ligi Kobiet, Program działania Ligi Kobiet w Międzynarodowym Roku Kobiet, ,Nasza Praca” 1975, nr 1-2.

\section{Monografie}

Fidelis M., Kobiety, komunizm $i$ industrializacja $w$ powojennej Polsce, przeł. M. Jaszczurowska, Grupa Wydawnicza Foksal, Warszawa 2015.

Grabowska M., Zerwana genealogia. Działalność społeczna i polityczna kobiet po 1945 roku a współczesny polski ruch kobiecy, Instytut Filozofii i Socjologii PAN, Warszawa 2018.

Madejska M., Aleja włókniarek, Wydawnictwo Czarne, Wołowiec 2018.

Ratman-Liwerska I., Stowarzyszenie jako czynnik społeczno-wychowawczej aktywizacji kobiet (na przykładzie badań na Białostocczyźnie), Dział Wydawnictw Filii UW, Białystok 1984.

\section{Artykuły w pracach zbiorowych}

Dajnowicz M., Działalność Społeczno-Obywatelskiej Ligi Kobiet w świetle „Naszej Pracy” (1947-1949), [w:] M. Dajnowicz, A. Miodowski (red.), Polityka i politycy w prasie XX i XXI wieku, Wydawnictwo Uniwersytetu w Białymstoku, Białystok 2016.

Dajnowicz M., Posłanki Ligi Kobiet Polskich i wybory parlamentarne 1989 roku (prezentacja w świetle „Zwierciadła”), [w:] M. Dajnowicz, A. Miodowski (red.), Polityka i politycy w prasie XX i XXI wieku. Polityka w prasie kobiecej, Wydawnictwo Uniwersytetu w Białymstoku, Białystok 2018.

Musiałowa A., „Walka o pokój” w wypowiedziach propagandowych publikowanych na łamach „Naszej Pracy” - biuletynie Ligi Kobiet (1947-1953), [w:] E. Maj, W. Sokół, A. Szwed-Walczak, Ł. Jędrzejski (red.), Bezpieczeństwo Europy Bezpieczeństwo Polski: Metamorfozy bezpieczeństwa. Teraźniejszość i przeszłość, t. 5, Wydawnictwo UMCS, Lublin 2017.

\section{Artykuły w czasopismach naukowych}

Andrejuk K., Awans społeczny kobiet w czasach PRL. Dynamika struktury i sprawczości, „Przegląd Socjologiczny” 2016, t. 3.

Dajnowicz M., „Zwierciadło” - platforma polityczna Ligi Kobiet $w$ okresie PRL (1957-1961, 1982-1989), „Rocznik Historii Prasy Polskiej” 2017, nr 3.

Dajnowicz M., Główne kierunki działalności Ligi Kobiet w Polsce Ludowej do 1975 roku (ze szczególnym uwzględnieniem województwa białostockiego), „Prace Historyczne" 2018, nr 145(3).

Dajnowicz M., Liga Kobiet w okręgu łódzkim w latach 1945-1981. Główne obszary działalności, „Dzieje Najnowsze” 2019, nr 4. 
Dajnowicz M., Liga Kobiet $w$ terenie. Kierunki działalności organizacji na przykładzie struktur białostockich w latach 1966-1981, „Niepodległość i Pamięć” 2018, t. 25, nr 2.

Drozdowska A., Liderki Ligi Kobiet wobec wyborów w latach 80. (W świetle „Naszej Pracy”), „Czasopismo Naukowe Instytutu Studiów Kobiecych” 2020, nr 1(8).

Drozdowska A., Liga Kobiet $w$ województwie białostockim - stan badań i postulaty badawcze, „Czasopismo Naukowe Instytutu Studiów Kobiecych” 2018, nr 2(5).

Miodowski A., Local conditions for the activities of the League of Women structures in the Lower Silesia during the Stalinist period, „Społeczeństwo i Polityka” 2018, nr 4(57).

Miodowski A., Udział dolnośląskiej Ligi Kobiet w kampaniach propagandowych na rzecz aktywizacji zawodowej kobiet ze środowisk patologicznych i aspołecznych (1949-1955), „Niepodległość i Pamięć” 2019, t. 26, nr 1.

Musiałowa A., Zadania kobiet polskich w walce o pokój i plan 6-letni, „Nasza Praca” 1951, nr 6-7. 